\title{
Physics losing the corporate struggle
}

SQUEEZED by economics and a corporate preoccupation with the bottom line, three of the largest US companies doing basic physics research are cutting back operations and reducing their research staff. AT\&T's Bell Laboratories, Bellcore and IBM are all shifting their research programmes to applied research, a move that has already closed laboratories and left dozens of researchers looking for jobs. In time the move is expected to eliminate more than 300 full-time basic research positions.

At Bellcore, the research consortium begun nine years ago after a federal judge split the Bell Telephone monopoly into seven regional 'Baby Bells', basic research is near extinction. Of the 100 full-time $\mathrm{PhD}$ research positions now devoted to basic research at Bellcore, only about 50 will be left when the consortium completes its restructuring later this year. "We don't intend to continue any basic research as an isolated entity," says Murrae Bowden, assistant vice president for network technology research.

Superconductivity and nanofabrication research are being phased out, he says, part of a broader shift away from condensed-matter physics. In its place will be more software technology. "This industry is driven largely by software," says Bowden. "You have to ask yourself, how far down the chain of research do the owners want us to go?"

Bell Labs, traditionally the top of the heap in industrial basic physics research, is also moving away from its roots. "We are making a shift from the material and physical sciences to software research," says Kumar Patel, director of the division of materials science and engineering. After decades of steady profits from its monopoly ownership of the telecommunications market, AT\&T is now fighting for its corporate life against stiff competition. And it is finding long-term research hard to justify.

So far the cuts have been modest, although corporate officials do not rule out the possibility that Bell Labs will one day bow out of basic research. Some of the eliminated programmes - such as the one in astrophysics - go back for more than 50 years. "But if we're going to pay Peter, we've got to rob Paul," explains Patel. "This kind of redirection is never easy, but I think that people understand the needs of the corporation."

Patel says that the balance between basic and applied research - 60:40 five years ago and 55:45 now — in five years will favour applied research, a transition that will eliminate about 100 basic research positions. Attrition, rather than layoffs, will cover the reductions. "Under normal circumstances," Patel says, "we'd hire maybe 20 new people each year. Now maybe we'll hire 10."

Along with astrophysics, Bell Labs is phasing out most of its basic superconductivity research. Despite the Nobel Prize won by two Bell researchers - Robert Wilson and Arno Penzias, the current vice president for research - for discovering in 1965 the background radiation that offered evidence of the Big Bang, astrophysics "doesn't really couple with the needs of the company anymore", says Patel. And in superconductivity, Bell is dropping most of its research on the basic properties of the materials in favour of applied research on superconducting wires and the like. The one exception is superconductivity in $\mathrm{C}_{60}$, the new-found form of carbon.

IBM, another traditional behemoth in basic physics research, is making a more gradual shift. Despite experiencing the first money-losing quarter in the company's history last year, IBM is not abandoning basic research, says James McGroddy, vice president in charge of research. Its corporate evolution has been in the making for the past ten years, he says, and is a transition from research at the bottom of the "food chain" to more work at the applied end. Nevertheless, although IBM's overall research budget has remained essentially flat over the past several years, the shift to applied research within that total is expected to mean the loss of about 100 basic research positions in the next few years.

Behind this widespread corporate retreat from basic research is the changing nature of the US electronics and telecommunications industry. In 1980, when AT\&T and IBM were virtually unchallenged in their respective fields, such big companies maintained heavily endowed basic research laboratories almost as a matter of pride. AT\&T, for example, was legally required to spend a percentage of its income on basic research in exchange for its monopoly position before the breakup. In a span of 40 years, such an emphasis produced the transistor and half a dozen Nobel prizewinners.

But AT\&T must now compete for its market share, just like any other big company. For both the new Bell Labs and Bellcore, this has come as something of a shock. "The old Bell Labs had a key advantage - it couldn't fail," says Bellcore's Bowden. "We can."

After the breakup of the Bell system, Bellcore "came out of it with a mindset that our model of research was the Bell Labs model," Bowden says. That is, the best basic research and plenty of it. "We were like a kid in a candy store," he says. "We put too great an emphasis on materials research. It took some time to get it straight."
By the time the dust had settled, Bellcore's new owners were asking why they should be supporting a basic research programme when they are forbidden by law to manufacture products. The answer from scientists - that research would make the telephone companies a more "educated consumer" of high technology - was not persuasive.

Facing competition on all fronts, AT\&T was also asking what its legendary research division had done lately. In 1989 , the word came down that the old model of freewheeling and unencumbered basic science at Bell Labs would have to go. Now, says Patel, "we have a narrow view of what's important to us in the long run. What we call basic research is what fits the general needs of the company."

Researchers say these three companies may be only the most visible examples of the decline of basic industrial research. What is happening at Bell Labs, IBM and Bellcore "is not very different from what's going on in research labs throughout industry," says John Rowell, former directory of Bellcore's research programme and now vice president for research at Conductus Inc., a superconductivity startup (see story on facing page). As the person who built up Bellcore's research programmes in the first place, Rowell is unhappy with the fact that companies with a combined annual income of $\$ 90,000$ million employ fewer than 100 basic researchers.

"One person in basic hardware research for every $\$ 1$ billion in revenue is a pathetic amount", says Rowell. "As far as the Bells go, anything that can not be immediately applied to telephone research isn't going to happen. And immediately means a year or less. To my mind that's not research."

Christopher Anderson

\section{US SPACE PROGRAMME}

\section{Industrialist to NASA}

DANiEL Goldin, an executive at TRW and a virtual unknown in the space community, was nominated last week to be the new head of the National Aeronautics and Space Administration (NASA). An engineer who now manages his company's work on military satellites and the Strategic Defence Initiative's 'Brilliant Pebbles' project, Goldin is seen as someone who would strongly support the Administration's space policy, including the planned Mars mission and the space station and a phaseout of the shuttle fleet. Critics saw the nomination as further evidence of NASA's domination by the National Space Council and its chair, vice-president Dan Quayle, and vow to oppose the nomination.

Christopher Anderson 